\title{
Analisis Level Kesiapan Warga Menghadapi Potensi Bencana Longsor Kota Semarang
}

\author{
Novie Susanto $^{1 *}$, Thomas Triadi Putranto ${ }^{2}$ \\ ${ }^{1}$ Program Studi Teknik Industri, Fakultas Teknik, Universitas Diponegoro, Semarang, Indonesia \\ ${ }^{2}$ Program Studi Teknik Geologi, Fakultas Teknik, Universitas Diponegoro, Semarang, Indonesia
}

\begin{abstract}
ABSTRAK
Semarang memiliki morfologi bervariasi yang berpotensi terhadap bencana tanah longsor. Daerah rawan longsor ini mengakibatkan kerugian yang tidak sedikit baik sisi ekonomi sosial seperti bangunan (vihara, talud, rumah dan sebagainya) maupun nyawa manusia. Dalam hal ini manusia banyak dirugikan meskipun aktivitas manusia juga terdeteksi sebagai salah satu penyebab utama terjadinya bencana longsor. Untuk mengurangi kerugian yang mungkin ditimbulkan oleh bencana longsor di Kota Semarang perlu diketahui status kesiapsiagaan warga sehingga prioritas sosialisasi dan intervensi dapat terarah dengan baik. Metode yang digunakan dalam penelitian ini adalah mengukur indeks kesiapsiagaan warga di 19 lokasi titik penelitian rawan bencana longsor. Hasil penelitian menunjukkan secara umum, kesiapsiagaan masyarakat Semarang masuk dalam kategori "Hampir Siap" dengan nilai indeks 55,74. Terdapat 2 lokasi yang memiliki indeks kesiapsiagaan "BelumSiap" yaitu Kembang Arum dan Manyaran. Daerah Mangunharjo berada dalam kategori indeks cukup siap. Ketiga daerah ini berada di daerah dengan tingkat kerawanan cukup tinggi sehingga diprioritaskan untuk mendapatkan sosialisasi dan intervensi yang diperlukan.
\end{abstract}

Kata Kunci: indeks kesiapsiagaan; longsor; Kota Semarang; petakesiapan

\begin{abstract}
[Title: Analysis of Citizens' Preparedness Level toward Potency of Landslides Disaster in Semarang Cityl Semarang has different morphology and by doing so caused a high potential for landslides. This case resulted in the losses of the landslide-prone area both for the social economy such as buildings (temples, embankments, homes, etc.) and human lives. In this case, the man obtained many disadvantages although human activity is also detected as one of the main causes of the landslide. To reduce the losses, it is needed to know the status of citizens' preparedness so that the priority of socialization and interventions can be targeted properly. The method used in this study is the measurement of the preparedness index of residents in 19 locations of landslides-prone areas. The results showed in general, the community preparedness Semarang in the category "Almost Ready" with an index value of 55.74. There are two locations that have an index of preparedness "Not Ready" namely Kembang Arum and Manyaran. Mangunharjo area is in the category of the index "Quite Ready". Those areas are located in areas with fairly high degree of vulnerability. So they are prioritized for the socialization and the interventions.
\end{abstract}

Key Words: Preparedness Index; landslides; Semarang City; preparedness map

\section{Pendahuluan}

Semarang memiliki morfologi bervariasi yang berpotensi terhadap bencana tanah longsor. Prakiraan curah hujan yang cukup tinggi yaitu 150-400 $\mathrm{mm} /$ bulan di bulan Maret 2015 (BMKG, 2015) memberikan sisi positif terjaminnya pasokan air namun sisi negatif yaitu kekhawatiran akan timbulnya bahaya geologi lainnya, yakni bencana tanah longsor di beberapa tempat yang rawan terhadap longsor juga ada. Tercatat pada bulan Januari 2015, kejadian di Kampung Trangkil Baru, Kelurahan Sukorejo, Kecamatan Gunungpati, Kota

*PenulisKorespondensi.

E-mail: novie.susanto@ft.undip.ac.id
Semarang, itu terjadi selama dua hari berturut-turut sejak Rabu hingga Kamis, 23 Januari 2014 (Faisol, 2015). Selain itu dari catatan Badan Penanggulangan Bencana Daerah/BPBD Kota Semarang untuk Tahun 2012 (Purba, 2014) sebanyak 27 kejadian tanah longsor di Kota Semarang dipicu oleh hujan deras yang terjadi selama beberapa waktu. Lokasi longsor terjadi di Kecamatan Candisari, Gajahmungkur, Ngalian, Semarang Barat, Pedurungan dan Tembalang. Selain diakibatkan oleh curah hujan yang tinggi, kondisi geologi yang meliputi morfologi daerah tersebut seperti perbukitan dan slope, keberadaan struktur geologi (sesar) yang mengontrol, serta kondisi litologi/batuan yang menyusun daerah tersebut.

Kerawanan bencana longsor di Kota Semarang terbagi dalam 5 (lima) tingkat (Purba, 
2014) yaitu sangat rawan, rawan, cukup rawan, agak rawan, dan tidak rawan. daerah yang sangat rawan tersebar setempat-setempat di bagian selatan (Mijen, Banyumanik, Semarang Barat dan Ngalian) sekitar $0,31 \%$, sementara zona rawan tersebar sebesar $1,20 \%$ tersebar di (Ngalian, Mijen, Gunungpati, Candisari, Banyumanik, Tembalang, Pedurungan). Zona cukup rawan tersebar sebesar $13,3 \%$ sedangkan dominan adalah agak rawan sebanyak 60,5\% sisanya $24,7 \%$ tidak rawan yang terletak di utara Kota Semarang. Lokasi cukup rawan dan agak rawan longsor tersebar dominan dari bagian tengah (Perbukitan Candi) hingga kawasan perbukitan di selatan Kota Semarang (Purba, 2014).

Daerah rawan longsor ini mengakibatkan kerugian yang tidak sedikit baik sisi ekonomi sosial seperti bangunan (vihara, talud, rumah dan sebagainya) maupun nyawa manusia (BNPB, 2015). Longsor memang terjadi karena proses alami dalam perubahan struktur muka bumi, yakni adanya gangguan kestabilan pada tanah atau batuan penyusun lereng yang dipengaruhi oleh kondisi geomorfologi namun beberapa hasil aktivitas manusia yang tidak terkendali dalam mengeksploitasi alam juga dapat menjadi faktor penyebab ketidakstabilan lereng yang dapat mengakibatkan terjadinya longsor. Dalam hal ini manusia banyak dirugikan meskipun aktivitas manusia juga terdeteksi sebagai salah satu penyebab utama terjadinya bencana longsor.

Untuk mengurangi kerugian yang mungkin ditimbulkan oleh bencana longsor di Kota Semarang ada beberapa hal yang dapat dilakukan. Pemetaan perilaku manusia berbasis kepentingan manusia (human-centered design) oleh Susanto dan Putranto (2015) menerangkan tingkat pemahaman pengetahuan masih rendah dan kesalahan tindakan dilakukanoleh warga cukup tinggi terkait bencana longsor di daerahnya. Pemberdayaan masyarakat sangat diperlukan untuk meningkatkan keberhasilan penanganan bencana. Kebijakan dan program yang dilakukan oleh Pemerintah Kota Semarang selama ini masih berfokus kepada institusi pemerintah sebagai pihak yang melayani tanggap darurat dan pasca bencana padahal masyarakat umum terutama penduduk di daerah rawan bencana sangat memerlukan pembinaan dan pendidikan memadai mengenai kondisi daerahnya (Susanto dan Putranto, 2015). Penelitian lain oleh Sriyono (2012) menghasilkan peta rawan bencana longsor dan sebaran bencana longsor di Kecamatan Banyubiru, Kabupaten Semarang. Metode lain yang dapat digunakan untuk mengetahui tingkat kesiapsiagaan warga adalah dengan mengetahui indeks kesiapsiagaan. Dengan mengetahui nilai indeks ini, prioritas sosialisasi dapat diketahui dan tindakan yang seharusnya diambil dapat dilakukan.

Studi kesiapan warga dalam menghadaoi bencana telah banyak diteliti di Indonesia. Firmansyah dkk. (2014) meneliti hubungan pengetahuan dengan perilaku kesiapsiagaan dalam menghadapi bencana banjir dan longsor pada remaja usia 15-18 tahun di SMA Al-Hasan Kemiri Kecamatan Panti Kabupaten Jember. Rante dkk. (2015) meneliti tingkat kesiapsiagaan rumah tangga mengahadapi bencana alam tanah longsor di Kelurahan Battang Barat Kecamatan Wara Barat Kota Palopo tahun 2012. Indeks kesiapsiagaan dikembangkan oleh UNESCO-LIPI (Nugroho, 2007) dan telah diimplementasikan pada banyak studi kasus manajemen bencana. Nugroho (2007) menganalisis kesiapsiagaan warga di Nias terkait bencana gempa bumi dan tsunami dengan metode kuantitatif indeks kesiapsiagaan dilihat dari sisi individu dan rumah tangga, komunitas sekolah dan pemerintah.

Penelitian ini mengacu pada indeks kesiapsiagaan yang dikembangkan oleh UNESCOLIPI tersebut dan ditujukan pada responden secara individu. Tujuan penelitian ini adalah untuk mengidentifikasi tingkat kesiapan warga dalam menghadapi bencana longsor. Indeks kesiapsiagaan akan digunakan sebagai input penentuan prioritas sosialisasi dan bahan desain intervensi kognitif yang diperlukan untuk meningkatkan indeks kesiapsiagaan warga. Dengan demikian kerugian yang mungkin timbul akibat ketidaksiapan warga dapat berkurang.

\section{Metode Penelitian}

Penelitian dilakukan bersamaan dengan pemetaan perilaku (Susanto dan Putranto, 2015) dan studi geolistrik. Lokasi penelitian dilakukan di 19 titik lokasi penelitian yang termasuk dalam area sangat rawan, agak rawan dan rawan bencana longsor (Susanto dkk., 2015). Kuesioner untuk mengetahui indeks kesiapsiagaan disebar kepada 107 warga secara acak.

Materi kuesioner mencakup pemahaman warga mengenai pencegahan bencana tanah longsor, situasi tanggap darurat, pengelolaan bencan ada mobilisasi sumber daya. Kuesioner bersifat tertutup dengan kombinasi kuesioner terbuka untuk pertanyaan tertentu. Kuesioner tertutup dipilih karena responden memiliki latar belakang pendidikan dan pengetahuan bencana yang bervariasi dan jumlah responden cukup banyak. Kuesioner tertutup akan mengurangi waktu wawancara dan mempermudah analisis kuantitatif. Kuesioner didesain berdasarkan adaptasi kuesioner yang digunakan oleh YPM dan JICA (2010) untuk pengambilan data persiapan sub proyek sistem peringatan dini dan evakuasi dini di kabupaten Jember terkait kesadaran masyarakat dan pemerintah setempat.

Wawancara mendalam terhadap responden dilakukan secara terintegrasi dengan pembagian kuesioner melalui desain materi wawancara yang terstruktur. Materi wawancara meliputi pertanyaan mengenai pengalaman dan strategi pengelolaan bencana di daerah masing-masing.

Pengolahan data dilakukan berdasarkan metode penentuan indeks kesiapsiagaan (Nugroho, 
2007). Kesiapsiagaan dikelompokkan kedala mempat parameter yaitu pengetahuan dan sikap / Knowledge and Attitude (KA), perencanaan kedaruratan / Emergency Planning (EP), system peringatan / Warning System (WS) dan mobilisasi sumberdaya (RMC). Pengetahuan mencakup ciri-ciri, gejala dan penyebabnya. Perencanaan kedaruratan mencakup tindakan apa yang sudah disiapkan. Sistem peringatan mencakup usaha yang ada di masyarakat dalam mencegah terjadinya korban akibat bencana dengan tanda peringatan yang ada. Mobilisasi sumber daya adalah keterampilan atau kesiapan sumberdaya di masyarakat tersebut. Indeks kesiapan diformulasikan seperti terlihat pada Formula (1), sedangkan kategori nilai indeks dapat dilihat pada Tabel 1.

Hasil perhitungan indeks kesiapan dilakukan untuk setiap parameter di Kota Semarang secara umum dan di setiap titik lokasi penelitian.

Indeks Kesiapan $=\frac{\text { Total Riil Parameter }}{\text { Skor Maksimum Parameter }} \times 100 \ldots \ldots$

Tabel 1. Kategori nilai indeks kesiapan

\begin{tabular}{ccc}
\hline No. & NilaiIndeks & Kategori \\
\hline 1 & $80-100$ & Sangat Siap \\
2 & $65-79$ & Siap \\
3 & $55-64$ & Hampir Siap \\
4 & $40-54$ & Kurang Siap \\
5 & $0-39$ & Belum Siap \\
\hline
\end{tabular}

\section{Hasil dan Diskusi}

\subsection{Indeks Kesiapan di Kota Semarang}

3.1.1. Pengetahuan tentang bencana (KA) di Semarang

Secara umum, pengetahuan yang dimiliki oleh responden mengenai bencana cukup tinggi. Dari pertanyaan-pertanyaan yang diberikan kepada responden, hamper seluruhnya mengetahui pengetahuan dasar mengenai tanah longsor. Jika diukur dengan menggunakan skor parameter, untuk parameter Pengetahuan dan Sikap (KA) maka didapatkan hasil sebesar 78,3. Besar skor jika dilihat dengan tabel indikator tingkat kesiapsiagaan maka masuk ke dalam kategori siap.

Pengetahuan yang didapatkan oleh masyarakat berasal dari kemandirian mereka dalam mendapatkan informasi tersebut. Hal ini dapat diartikan bahwa kontribusi pihak luar seperti agen sosialiasai mengenai kesiapsiagaan bencana dan pemerintah masih belum terlihat. Melalui hasil kuisioner, didapatkan bahwa sumber informasi paling besar berasal dari TV dengan hasil 91,6\%, radio (40.2\%) dan koran / majalah (29,9\%). Sebanyak 32,7\% responden akan meninggalkan tempat tinggal yang sekarang apabila wilayah tempat tinggalnya terkena bencana tanah longsor. Hal ini berarti terdapat $67,3 \%$ warga yang akan tetap tinggal walaupun daerah tempat tinggalnya terkena bencana longsor. Alasan masyarakat tetap tinggal ada bermacam, 19,4\% beralasan bahwa sekarang tempat tinggalnya sudah aman, $20,9 \%$ beralasan bahwa mereka sudah nyaman dengan daerah tempat tinggal mereka sekarang, $2,78 \%$ beralasan bahwa mereka yakin tidak akan ada bencana longsor yang akan terjadi lagi dan sebesar $56,9 \%$ warga tidak ingin pindah karena tidak memiliki dana untuk pindah atau membeli rumah baru.

\subsubsection{Rencana Kesiapsiagaan Keluarga}

Secara umum, kesiap siagaan keluarga mengenai bencana cukup rendah. Jika diukur dengan menggunakan skor parameter, untuk parameter Kesiapsiagaan Keluarga maka didapatkan hasil sebesar 47,8. Besar skor jika dilihat dengan tabel indikator tingkat kesiapsiagaan maka masuk ke dalam kategori kurang siap. Hanya $4,60 \%$ dari warga Semarang yang memiliki rencana kesiapsiagaan khusus bagi keluarganya apabila terdapat bencana. Hanya $2,80 \%$ warga yang memahami rute pengungsian dikarenakan tidak adanya sosialisasi dari pemerintah mengernai rute pengungsian. Dan sebanyak $38,3 \%$ warga sudah mengetahui ramburambu tanda bencana seperti arah evakuasi.

\subsubsection{Sistem Peringatan}

Secara umum, system peringatan mengenai bencana longsor cukup tinggi. Jika diukur dengan menggunakan skor parameter, untuk parameter Sistem Peringatan maka didapatkan hasil sebesar 86,0 . Besar skor jika dilihat dengan tabel indikator tingkat kesiapsiagaan maka masuk ke dalam kategori sangat siap. Sistem peringatan yang digunakan oleh masyarakat dalam melakukan peringatan terhadap warga masih sangat sederhana yaitu dengan cara tradisional. Cara tradisional disini adalah berupa peringatan dengan menggunakan kentongan, pengumuman dengan toa dan peringatan dengan mengetuk rumah demi rumah yang ada (77\%). Sistem peringatan yang lain adalah pengumuman dari tempat ibadah (4\%), informasi dari pemerintah (4\%), kesepakatan lokal (13\%) dan informasi dari TVRI dan TV swasta (13\%).

\subsubsection{Mobilisasi Sumberdaya}

Secara umum, mobilisasi sumber daya mengenai bencana longsor sangat rendah. Jika diukur dengan menggunakan skor parameter, untuk parameter "Mobilisasi Sumberdaya" maka didapatkan hasil sebesar 17.5. Besar skor jika dilihat dengan tabel indikator tingkat kesiapsiagaan maka masuk ke dalam kategori belum siap. Hanya 7,48\% masyarakat yang pernah mengikuti kegiatan terkait dengan kesiapsiagaan bencana. Dengan 25\% memahami mengenai evakuasi korban bencana alam dan $75 \%$ memahami mengenai kepramukaan. 


\subsection{Indeks Kesiapsiagaan di Setiap Titik Lokasi}

Indeks kesiapsiagaan warga di setiap lokasi penelitian juga dihitung untuk menentukan prioritas lokasi yang akan mendapatkan upaya peningkatan indeks terutama di daerah dengan kerawanan tinggi. Rekapitulasi indeks kesiapan warga di tiap titik lokasi dapat dilihat pada Gambar 1. Seperti terlihat di Gambar 1, daerah yang perlu mendapatkan prioritas peningkatan indeks kesiapsiagaan adalah Manyaran dan Kembang Arum (kategori belum siap) serta Mangunharjo (kategori kurang siap). Seperti disebutkan dalam penelitian sebelumnya (Susanto dkk., 2015), Mangunharjo termasuk daerah berkategori cukup rawan bencana longsor, sedangkan Manyaran dan Kembang Arum termasuk dalam daerah berkategori rawan bencana longsor. Dengan demikian ketiga daerah ini menjadi prioritas utama kegiatan sosialisasi dan penerapan intervensi yang diperlukan untuk meningkatkan status kesiapsiagaannya.

Berdasarkan hasil penelitian dapat disimpulkan bahwa indeks kesiapan warga Kota Semarang bervariasi untuk setiap parameternya. Secara umum tingkat kesiapsiagaan warga berada pada kategori hamper siap dengan nilai indeks $55,5 \%$. Ringkasan perhitungan indeks untuk setiap parameter dapat dilihat pada adalah sebagai berikut
KA (78,3\%), EP (47,8\%), RMC (17,5\%) dan WS $(91,6 \%)$.

\section{Kesimpulan}

Secara umum, kesiapsiagaan masyarakat Semarang masuk dalam kategori "Hampir Siap" dengan nilai indeks 55,8. Posisi ini berada pada tingkatan ketiga kesiapsiagaan menghadapi bencana di bawah kategori "Sangat Siap" dan "Siap". Terdapat 2 lokasi yang memiliki indeks kesiap siagaan "Belum Siap" yaitu Kembang Arum dan Manyaran. Daerah Mangunharjo berada dalam kategori indeks cukup siap. Ketiga daerah ini berada di daerah dengan tingkat kerawanan cukup tinggi sehingga diprioritaskan untuk mendapatkan sosialisasi dan intervensi yang diperlukan. Studi selanjutnya sebaiknya terfokus pada desain intervensi kognitif untuk peningkatan indeks kesiapsiagaan di daerah rawan bencana serta implementasi desain ke daerah prioritas.

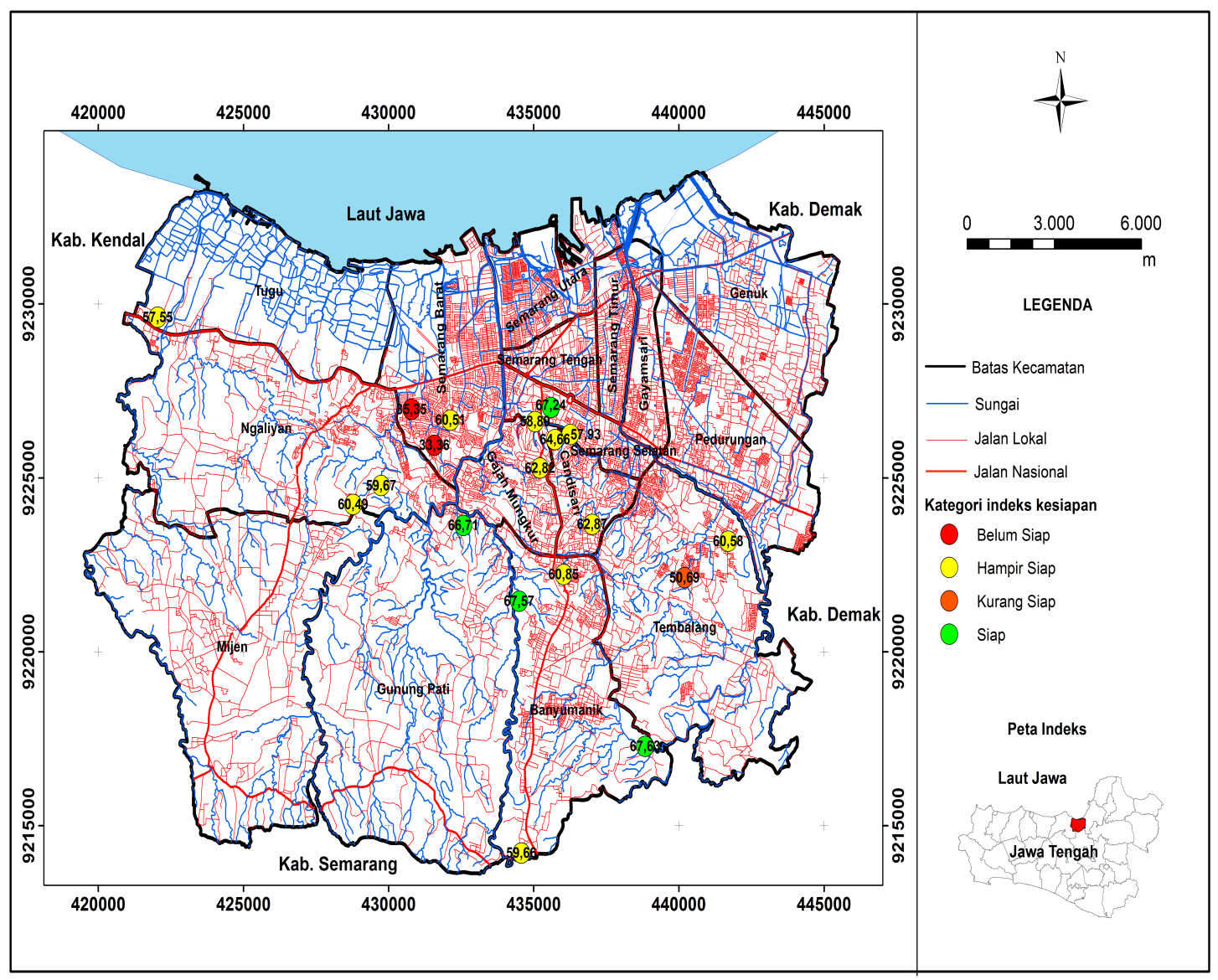

Gambar 1. Detail indeks kesiapsiagaan bencana longsor di tiap titik lokasi penelitian 


\section{Daftar Pustaka}

Badan Nasional Penanggulangan Bencana (BNPB), 2015. Data Kejadian Tanah Longsor. http://geospasial.bnpb.go.id/pantauanbencana/ data/datalongsorall.php [Online akses 14.12.2015].

Badan Meteorologi, Klimatologi dan Geofisika (BMKG) Semarang, 2015, Peta Prakiraan Curah Hujan Bulan Maret 2015 di Jawa Tengah, http://klimatologi.semarang.jateng.bmkg.go.id /index.php/en/2014-12-22-14-38-13/2014-1222-14-47-21/prakiraan-bulanan/186-prakich [Online akses 28.02.2015].

Faisol, E., 2005, Longsor di Semarang Rusak 25 Rumah Warga, http://www.tempo.co/read/news/2014/01/23/2 06547763/Longsor-di-Semarang-Rusak-25Rumah-Warga [Online akses 25.02.2015].

Firmansyah, I., Rasni, H., dan Rondhianto. 2014. Hubungan Pengetahuan dan Perilaku Kesiapsiagaan dalam Menghadapi Bencana Banjir dan Longsor pada Remaja Usia 15-18 tahun di SMA Al-Hasan Kemiri Kecamatan Panti Kabupaten Jember. Artikel Ilmiah Hasil Penelitian Mahasiswa 2014. Program Studi Ilmu Keperawatan Universitas Jember.

Nugroho, A.C. 2007. Kajian Kesiapsiagaan Masyarakat dalam Mengantisipasi Bencana Gempa Bumi dan Tsunami di Nias Selatan. MPBI-UNESCO. 2-20 April 2007.

Purba, J.O., 2014, Pembuatan Peta Zona Rawan Tanah Longsor Di Kota Semarang Dengan Melakukan Pembobotan Parameter, Skripsi Prodi Teknik Geodesi Undip, http://eprints.undip.ac.id/42838/ [Online akses: 20.02.2015].
Rante, A., Mantu, F.N, Patellongi, I., 2015. Tingkat Kesiapsiagaan Rumah Tangga Menghadapat Bencana Alam Tanah Longsor di Kelurahan Battang Barat Kecamatan Wara Barat Kota Palopo tahun 2012. Repository Universitas Hasanuddin Makassar.

Sriyono, A., 2012. Identifikasi Kawasan Rawan Bencana Longsor Kecamatan Banyubiru, Kabupaten Semarang. Skripsi. Jurusan Geografi, Fakultas Ilmu Sosial, Universitas Negeri Semarang.

Susanto, N. dan Putranto, T.T. 2015. How to develop a human-centered design of disaster management based on the human factor toolkits?: A case study of landslides area in Semarang City. Presented in the 2015 International Conference on Industrial Engineering Theory, Methodology, and Application. Yogyakarta, 27-28 Oktober 2015.

Susanto, N., Putranto, T.T, Dwijanto, J.S. Sahara, S.A., dan Puspaningtyas, D.A. 2015. Pengembangan Konsep Human-Centered Design dalam Pengelolaan Bencana Tanah Longsor di Kota Semarang. Prosiding 2nd Annual Conference in Industrial and System Engineering (2nd ACISE). Semarang, 7 Oktober 2015.

Yayasan Pengabdi Masyarakat (YPM) dan Japan International Cooperation Agency (JICA). 2010. Penelitian Dasar dan Persiapan untuk Sub Proyek Sistem Peringatan Dini dan Evauasi Dini di Kabupaten Jember: Kesadaran Masyarakat Setempat dan Pemerintah Setempat. Laporan Akhir Tim Kajian Yayasan Pengabdi Masyarakat. 